\title{
Prevalence and pathogenesis of some filarial nematodes infecting donkeys in Egypt
}

\author{
A. M. Radwan, N. E. Ahmed, L. M. Elakabawy, M. Y. Ramadan and R. S. Elmadawy
}

Department of Parasitology, Faculty of Veterinary Medicine, Banha University, Moshtohor, Toukh 13736, Egypt. Corresponding author: R. S. Elmadawy, e-mail: rehamelmadawy@hotmail.com, AMR: dr.ahmedradwan@yahoo.com, NEA: nagwa.mahmoud@fvtm.bu.edu.eg, LME: lubnaelakabawy@yahoo.com, MYR: ahmeduosif@yahoo.com Received: 30-03-2016, Accepted: 20-07-2016, Published online: 22-08-2016

doi: 10.14202/vetworld.2016.888-892 How to cite this article: Radwan AM, Ahmed NE, Elakabawy LM, Ramadan MY, Elmadawy RS (2016) Prevalence and pathogenesis of some filarial nematodes infecting donkeys in Egypt, Veterinary World, 9(8): 888-892.

\begin{abstract}
Aim: The primary objective of the present study is to determine the commonness of filarial parasites in donkeys in Egypt, identification of the filarial species tainting them and the delivered pathogenic impact connected with the infestation.

Materials and Methods: A total of 188 donkeys were examined for filarial infection. The blood samples and scraping of the cutaneous bleeding lesions were collected, stained, and inspected for microfilariae all through the period from March 2011 to October 2013. The adult worms were perceived in tissue samples acquired from skin scraping, testes, eyes, tendons, peritoneal and pleural cavities, and the ligamentum nuchae.

Results: On the basis of morphological identification, 163 of 188 donkeys $(86.70 \%)$ were infected with Onchocerca cervicalis (82.98\%), Setaria equina (31.11\%), Parafilaria multipapillosa (5.32\%), and Onchocerca reticulata (4.26\%). There was no significant effect of the sex on the incidence of all the encounteredfilarial worms except for $S$. equina, where the infection rate prevailed in males versus females (40.82\% vs. 35.90\%). In addition, age group of 5-15 years old exhibited a fundamentally higher predominance $(\mathrm{p}<0.05)$ of the recognized filarial worms versus those of $<5$ years old and $>15$ years old.

Conclusion: The preliminary results add to our comprehension of filarial species infecting donkeys in Egypt, their impact on animal execution and production. Accentuation must be taken for avoidance, control of filarial disease, and improvement of the management system of donkeys.
\end{abstract}

Keywords: age, donkey, Filaria, gender, prevalence.

\section{Introduction}

In Egypt, Donkeys, Equus asinus, are widely spread and economically important animals used for transport, whether riding, pack transport, or pulling carts. They provide more prominent mobility with which to face erratic rainfalls and are of worth in conveying firewood, loads, including water, household structures, goods, and children [1]. Filariasis is one of the most critical parasitic sicknesses affecting equines in Egypt. It is caused by different filarial species, namely, Onchocerca sp., Setaria equina, and Parafilaria multipapillosa. Substantial filaria infection in donkey is mainly associated with a destructive effect, including debilitation and limitation of the animal movement due to either affection of the ligamentum nuchae by Onchocerca cervicalis or affection of the flexor tendons and the suspensory ligaments of the forelegs by Onchocerca reticulata [2]. A severe inflammatory reaction is produced around

Copyright: Radwan, et al. Open Access. This article is distributed under the terms of the Creative Commons Attribution 4.0 International License (http://creativecommons.org/licenses/ by/4.0/), which permits unrestricted use, distribution, and reproduction in any medium, provided you give appropriate credit to the original author(s) and the source, provide a link to the Creative Commons license, and indicate if changes were made. The Creative Commons Public Domain Dedication waiver (http:// creativecommons.org/publicdomain/zero/1.0/) applies to the data made available in this article, unless otherwise stated. the dead worm, surrounded by fibrous tissue and the worm become calcified which may encourage the secondary bacterial invasion and abscess formation. Moreover, the filarial worms may migrate to unusual habitats such as ocular glob causing ocular dermatitis [3] and central nervous system causing serious pathogenic impacts [4]. Cases of eye infection with Setaria equina have been reported in human by Taylor et al. [5]. Whereas, human infection with Onchocerca sp. is associated with firm subcutaneously located nodules in the tendons of the muscles, knees, wrists, or feet [6]. In Egypt, there are few reports dealt with filariasis in donkeys, their prevalence or pathogenicity. Hence, the plan of the present study is to determine the commonness of filarial parasites in domestic donkeys (E. asinus) in Egypt, identify filarial species tainting them, assess the impact of sex and/or age on their prevalences, and to recognize the delivered pathogenic impact connected with the infestation.

\section{Materials and Methods}

\section{Ethical approval}

The collected samples in the present study were approved by the local committee of the Faculty of Veterinary Medicine, Benha University and according to the guidelines of the National Institute of Health in Egypt. 


\section{Animals}

The study was conducted on 188 donkeys that were submitted for slaughtering, and their meat was utilized as meals for wild animals in Giza zoo. Each donkey was physically examined before slaughtering for clinical signs or lesions created by filariasis.

\section{Samples}

For standard microscopic examination of microfilariae, $10 \mathrm{ml}$ of blood was collected from the jugular vein of each donkey in the early morning at 7- 8 am into dry elastic stoppered glass tubes containing $0.1 \mathrm{~g}$ ethylenediaminetetraacetic to be utilized for wet blood and stained thick blood smears preparations. Microfilariae were likewise perceived in scraping of presenting cutaneous bleeding lesions and by skin snip biopsy (measuring $2 \mathrm{~cm} \times 2 \mathrm{~cm}$ ) of the midline of the abdomen and umbilical region using cattle ear punch. The tissues were minced, suspended in $10 \mathrm{ml}$ distilled water, and incubated overnight at room temperature. The released microfilariae were concentrated by centrifugation at $500 \mathrm{rpm}$ for 10 minutes. The sediment was examined under microscope $(\times 10)$ for the movement of the microfilariae, then they were fixed with $2 \%$ formalin and stained by Giemsa stain or methylene blue 1:1000 for identification.

The adult worms were acquired from various tissues of the slaughtered donkeys. Ligamentum nuchae were removed, preserved in ice, dissected by peeling apart its two layers and the visible part of the $O$. cervicalis was gently grabbed. Flexor and extensor tendons and suspensory ligament were also inspected carefully for $O$. reticulata. Furthermore, peritoneal cavities, pleural cavities, scrotums, and eye were checked for the presence of $P$. multipapillosa or $S$. equina. Preparation of permanent mount of adult worm was done, and the morphological features of the filarial worms were distinguished as described by Soulsby [2].

\section{Gross pathology}

Fresh tissues were transported to the laboratory, and they were dissected using a stereo microscope for detection of the pathological changes associated with filarial nematodes.

\section{Statistical analysis}

Statistics was executed using two ways ANOVA under significance level of 0.05 for the entire results using SPSS (version 19).

\section{Results}

In the present survey, the evidence of filarial infection was experienced in $86.70 \%$ out of 188 inspected donkeys. O. cervicalis was the most abundant species $(82.98 \%)$ as compared with $S$. equina, $P$. multipapillosa, and $O$. reticulata $(36.17 \%, 5.32 \%$, and $4.26 \%$, respectively) (Table-1 and Figure-1).

No significant effect of the sex on the incidence of all the encountered filarial spp except for S. equina, where the infection rate prevailed in males versus females (40.82\% vs. 31.11\%) (Table-1). In general, There was a significant effect of age on the rate of filarial infection $(\mathrm{p}<0.05)$ which was more prevalent at donkeys 5-15 years of age $(61.70 \%)$ than those $>15$ years and $<5$ years of age $(57.45 \%$ and $9.57 \%$, respectively) (Table-2).

Filarial worms tended to influence distinctive parts of the body. O. cervicalis was confined to the nuchal ligament $(86.70 \%)$ (Figure-2a and b). O. reticulata was found in the suspensory and flexor tendons of the forelegs (4.26\%) (Figure-2c-e). S. equina occupied the peritoneal and pleural cavities and testes (36.17\% and 10\%, respectively). P. multipapillosa adult worms and microfilariae inhabited the subcutaneous tissues $(5.23 \%)$. Microfilariae of $O$. cervicalis and $O$. reticulata were exhibited in skin scraps and skin snips biopsies got from the midline of the abdomen, particularly umbilical region of $82.45 \%$ and $4.26 \%$ of donkeys, respectively. However, they were not observed in the blood. Microfilariae of $S$. equina were never detected all through the time of the study (Table-3).

$O$. cervicalis adult was seen entangled in cavities in the nuchal ligament or in the loose connective tissue and adipose tissues surrounding the ligament bringing about serious incendiary tissue sore in the nuchal ligament. The nuchal ligament of tainted donkeys of 5-year-old appeared grossly normal. Elder donkeys over 5-year-old suffered from caseation, mineralization, and granulomatous lesion of the nuchal ligament associated with the death of the parasites. The lesion ranged from focal isolated areas of 2-3 $\mathrm{mm}$ in diameter to a complete substitution of the normal ligament tissues (Figure-2f and g). O. reticulata was found in the suspensory and flexor tendons of forelegs causing inflammation and edema in place. S. equina was extricated from peritoneal and pleural cavities and testes with no observed gross lesion. P. multipapillosa

Table-1: Effect of gender on the prevalence of filarial nematodes.

\begin{tabular}{|c|c|c|c|c|c|}
\hline \multirow[t]{2}{*}{ Gender } & \multirow{2}{*}{$\begin{array}{c}\text { Number } \\
\text { infected }(\%)\end{array}$} & \multicolumn{3}{|c|}{ Infection (\%) } & \multirow[t]{2}{*}{ P. multipapillosa } \\
\hline & & o. cervicalis & o. reticulata & S. equina & \\
\hline Males $(n=98)$ & $85(86.73)^{\mathrm{aA}}$ & $80(81.63)^{\mathrm{aA}}$ & $5(5.10)^{\mathrm{ac}}$ & $40(40.82)^{a \mathrm{a}}$ & $4(4.08)^{a c}$ \\
\hline Female $(n=90)$ & $78(86.67)^{\mathrm{aA}}$ & $76(84.44)^{\mathrm{aA}}$ & $3(3.33)^{\mathrm{ac}}$ & $28(31.11)^{\mathrm{bB}}$ & $6(6.67)^{\mathrm{ac}}$ \\
\hline Total $(n=188)$ & $163(86.70)$ & $156(82.98)$ & $8(4.26)$ & $68(36.17)$ & $10(5.32)$ \\
\hline
\end{tabular}

Different superscripts letters $(a, b, c)$ in the same column indicate significant differences at $p<0.05$. Different superscripts letters $(A, B, C)$ in the same row indicate significant differences at $p<0.05$. 0 . cervicalis=Onchocerca cervicalis, S. equina =Setaria equina, O. reticulata=Onchocerca reticulate, $P$. multipapillosa=Parafilaria multipapillosa 


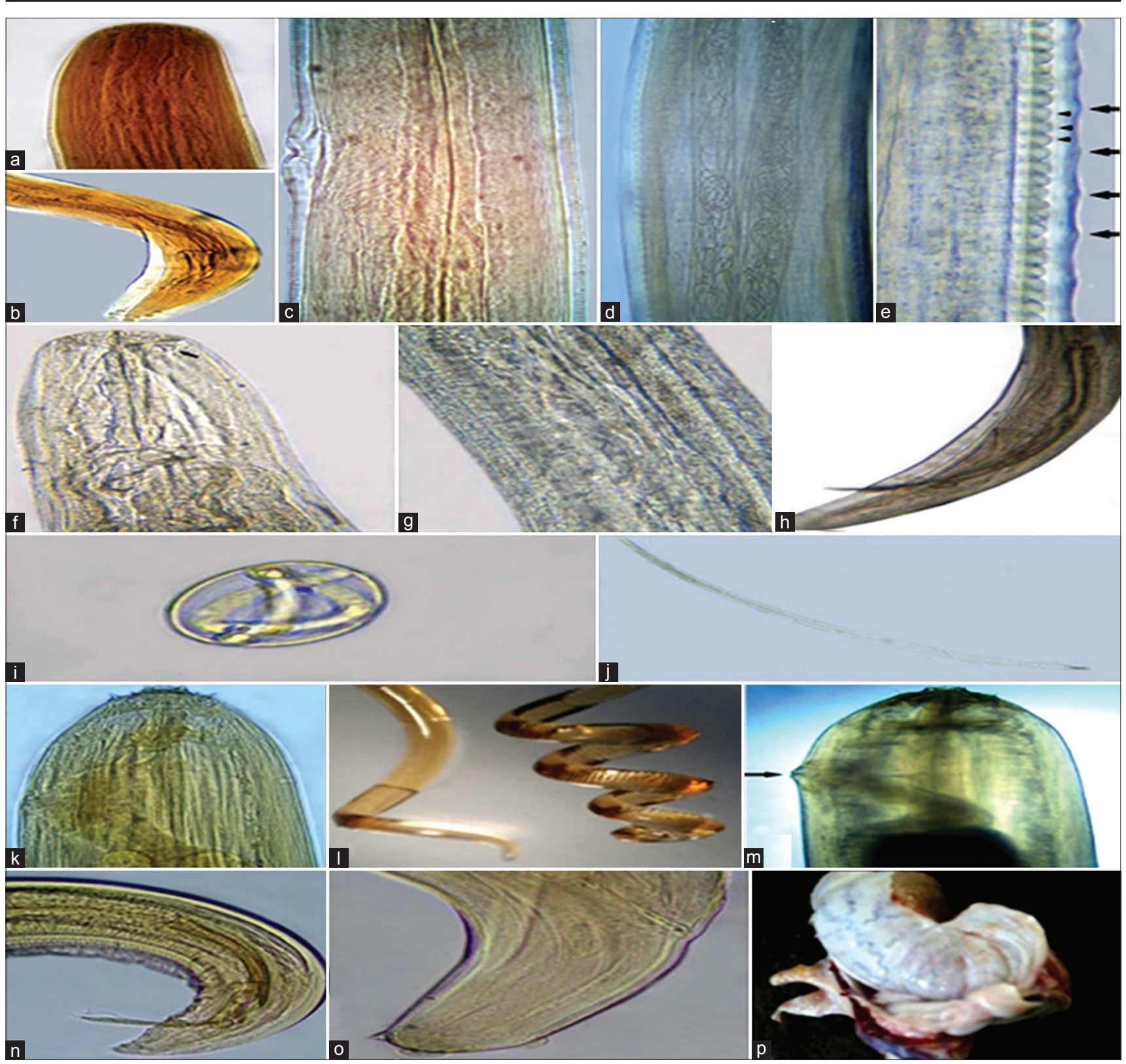

Figure-1: Onchocerca cervicalis: (a) Anterior end, (b) male posterior end, (c) vulva, (d) microfilariae in the uterus of female (e) middle region of female showing low widely spaced indistinct external cuticular annulations (large arrows) and internal striations forming elongated cells (small arrowheads); Parafilaria multipapillosa: (f) Anterior end (arrow refers to vulva anteriorly near the mouth opening), $(g)$ Uteri in the middle region, (h) male posterior end, (i) embryonated egg with thin flexible shell, $(j)$ microfilaria with rounded posterior extremity; Setaria equina: (k) Anterior end, (I) coiled male posterior end (right) and female (left), (m) female vulva, ( $n$ ) male posterior end, (o) female posterior end, (p) adult worm encapsulated between the testicular tunica.

Table-2: Effect of age on the prevalence of filarial nematodes.

\begin{tabular}{lccc}
\hline Filarial & \multicolumn{3}{c}{ Infection $(\%)$} \\
\cline { 2 - 4 } nematodes & $\begin{array}{c}<\mathbf{5} \text { years } \\
(\mathbf{n = 2 9 )}\end{array}$ & $\begin{array}{c}\mathbf{5 - 1 5} \text { years } \\
(\mathbf{n = 9 1 )}\end{array}$ & $\begin{array}{c}\mathbf{1 1 5} \text { years } \\
(\mathbf{n = 6 8})\end{array}$ \\
\hline O. cervicalis & $11(37.93)^{\mathrm{aB}}$ & $77(84.62)^{\mathrm{aA}}$ & $68(100)^{\mathrm{aA}}$ \\
O. reticulata & $0(0)^{\mathrm{bA}}$ & $3(3.30)^{\mathrm{CA}}$ & $5(7.35)^{\mathrm{CA}}$ \\
S. equina & $7(24.14)^{\mathrm{abA}}$ & $33(36.26)^{\mathrm{bA}}$ & $28(41.18)^{\mathrm{bA}}$ \\
P. multipapillosa & $0(0)^{\mathrm{bA}}$ & $3(3.30)^{\mathrm{CA}}$ & $7(10.29)^{\mathrm{cA}}$ \\
Total $(\mathrm{n}=188)$ & $18(9.57)^{\mathrm{C}}$ & $116(61.70)^{\mathrm{A}}$ & $108(57.45)^{\mathrm{B}}$ \\
\hline
\end{tabular}

Different superscripts letters $(a, b, c)$ in the same column indicate significant differences at $p<0.05$. Different superscripts letters $(A, B, C)$ in the same row indicate significant differences at $\mathrm{p}<0.05$. O. cervicalis=Onchocerca cervicalis, $S$. equina $=$ Setaria equina, $O$. reticulata $=$ Onchocerca reticulata, P. multipapillosa=Parafilaria multipapillosa brought on a hemorrhagic dermatitis with inflammation the subcutaneous and intramuscular tissue accompanied by extensive edema.

\section{Discussion}

The findings that $86.70 \%$ out of 188 examined donkeys were infected with filarial nematodes, and $O$. cervicalis appeared to be the most common species $(82.98 \%)$ were consistent with the previous report Bahnass [7] who found filarial worm infestation in $84.5 \%$ of donkeys in Sharkia province in Egypt. On the contrary, a lower incidence was recorded by El-Wahab and Raef [8] (65.38\%). The incidence of S. equina (36.17\%) concurred with that reported by Radwan [9]. 

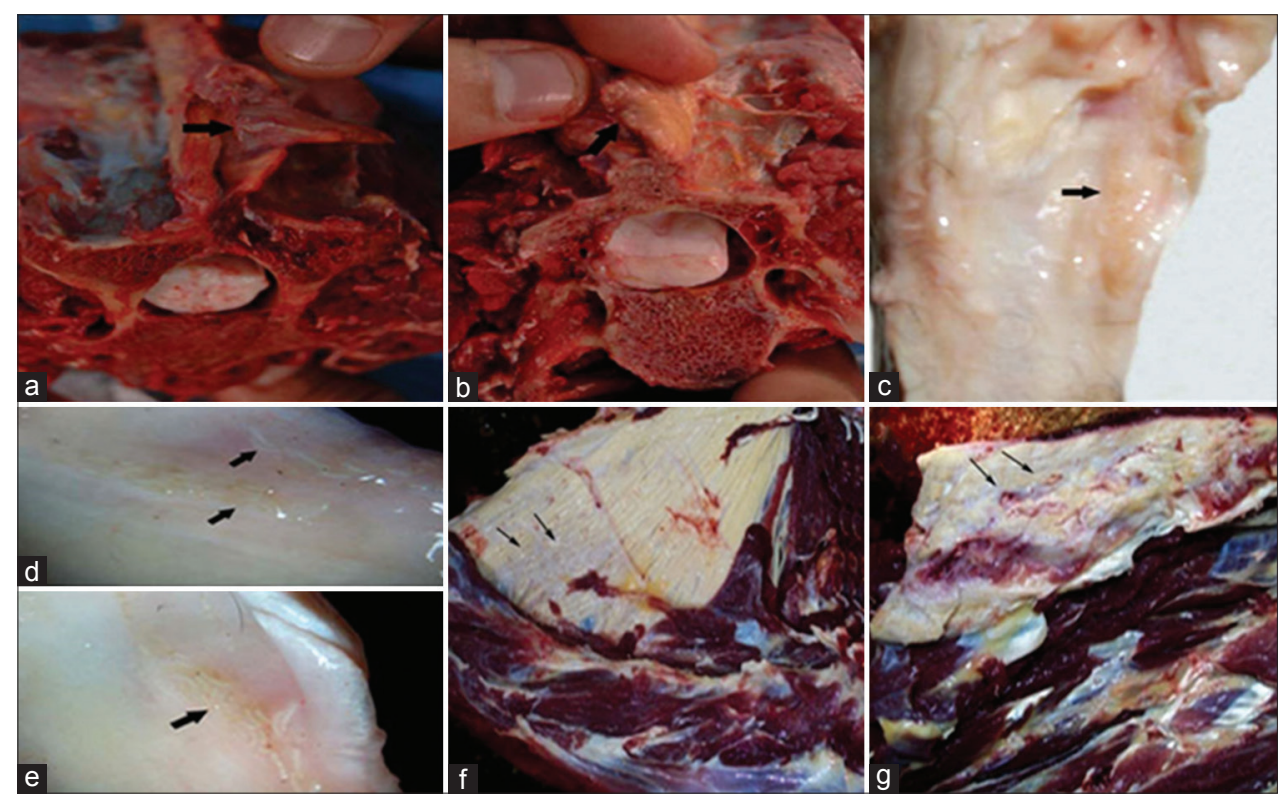

Figure-2: ( $a$ and b) Onchocerca cervicalis adults in the insertion point of the nuchal ligament (lamellar part); (c-e) Onchocerca reticulata adult worms in the flexor and suspensory ligaments of the forelegs; $(f, g)$ Nuchal ligaments suffering from fibrosis and calcification due to $O$. cervicalis.

Table-3: Frequency of filarial nematodes in different tissues at PM examination.

\begin{tabular}{|c|c|c|c|c|c|c|c|}
\hline \multirow[t]{3}{*}{ Filarial nematodes } & \multicolumn{7}{|c|}{ Infection (\%) } \\
\hline & \multicolumn{5}{|c|}{ Adult worms } & \multicolumn{2}{|c|}{ Microfilariae } \\
\hline & $\begin{array}{l}\text { Nuchal } \\
\text { ligament } \\
(n=188)\end{array}$ & $\begin{array}{c}\text { S\&F } \\
\text { tendons } \\
(\mathrm{n}=188)\end{array}$ & $\begin{array}{c}\text { P\&P } \\
\text { cavities } \\
(\mathrm{n}=\mathbf{1 8 8})\end{array}$ & $\begin{array}{c}\text { Testes } \\
(n=150)\end{array}$ & $\begin{array}{c}\text { Eyes } \\
(\mathrm{n}=376)\end{array}$ & $\begin{array}{c}\text { Skin } \\
(\mathbf{n}=\mathbf{1 8 8})\end{array}$ & $\begin{array}{c}\text { Blood } \\
(n=188)\end{array}$ \\
\hline O. cervicalis & $163(86.70)$ & $0(0)$ & $0(0)$ & $0(0)$ & $0(0)$ & $155(82.45)$ & $0(0)$ \\
\hline O. reticulata & $0(0)$ & $8(4.26)$ & $0(0)$ & $0(0)$ & $0(0)$ & $8(4.26)$ & $0(0)$ \\
\hline S. equina & $0(0)$ & $0(0)$ & $68(36.17)$ & $15(10)$ & $0(0)$ & $0(0)$ & $0(0)$ \\
\hline P. multipapillosa adult & $0(0)$ & $0(0)$ & $0(0)$ & $0(0)$ & $0(0)$ & $10(5.32)$ & $0(0)$ \\
\hline
\end{tabular}

The testis of some donkeys could not be examined because of castration. S\&F=Suspensory and flexor tendons of fore legs, $\mathrm{P} \& \mathrm{P}=$ Peritoneal and pleural cavities, $\mathrm{O}$. cervicalis=Onchocerca cervicalis, S. equina=Setaria equina, O. reticulata=Onchocerca reticulata, $P$. multipapillosa=Parafilaria multipapillosa, PM=Post mortem

This result was inconsistent with other previous investigators [10,11]. P. multipapillosa was found in 5.32\% of the examined donkeys, which agreed with the report of Arafa [12]. Alternately, a higher infection rate was recorded by Maloufi [13]. The lower incidence of O. reticulata $(4.26 \%)$ observed in this study disagreed with the result of Yousif et al. [14]. The recorded varieties in the prevalence of filarial nematodes might be credited to the environmental conditions which influence the continuance and transmission flow of the vectors and thus influence the severity and burden of filarial infection or to the degree of attention given by donkey owners to their animal management.

Severe pathological lesion associated with $O$. cervicalis adults in the ligamentum nuchae of elder donkeys was formerly seen by Jubb et al. [15]. In spite of the fact that, donkey eyes could be tainted with S. equina [16], this was not experienced in this study, where the regular destinations of $S$. equina were peritoneal and pleural cavities and testicles [10]. The intense hemorrhagic lesion that accompanied P. multipapillosa could be ascribed to the habit of the female of penetrating the skin to lay eggs and larvae [17].

In the present study, no significant effect of the sex on the incidence of all the encountered filarial speciesexcept $S$. equina, which its infection rate prevailed in males versus females (40.82\% vs. $31.11 \%)$. Furthermore, noticeable variety in filarial predominance was indicated by age, where filarial infection was more prevalent among donkeys of 5-15 years of age. In this respect, the prevalence of filariasis was formerly found to be higher in females than males (43\% vs. $31 \%)$ and in the age group of 7-16 versus $1-6$ years $(34.3 \%$ vs. $32.3 \%)$ [18]. On the other hand, Al Anazi et al. [10] found that the age did not have a significant effect on the incidence of $S$. equina.

Microfilariae of the encountered filarial worms were mainly recorded in skin biopsies or skin snips obtained from the midline of the abdomen, especially umbilical region and not perceived in the examined blood samples. In opposition, other researchers could identify blood microfilariae [19]. The difference could be explained by the tendency of Onchocerca sp. and P. multipapillosa females in producing microfilariae 
which migrate directly toward the skin and utilize umbilical region as predilection site [20]. Similar results were previously noticed by several researchers [21]. From our perspective, the absence of microfilariae in S. equina may be ascribed to the low level of microfilariae which make them difficult to be detected upon examination or to the high immunity of the host that restricts the circulation of microfilariae.

\section{Conclusion}

These preliminary results add to our understanding of filarial infection in donkeys in Egypt, their impact on animal performance and production. Accordingly, emphasis must be taken for prevention, control of filarial infection, and improvement of the management system of donkeys.

\section{Authors' Contributions}

Authors NEA and LME designed and conducted the study. AMR and MYR contributed in sample collection and application of the laboratory analysis. RSE contributed in collecting of samples and review of the literatures, analyzing data, drafting and revising the manuscript. All authors read and approved the final manuscript.

\section{Acknowledgments}

The authors appreciate the effort given by the Center of Excellence in Scientific Research (CESR) of Veterinary Medicine, Benha University that provided the necessary funds throughout the study.

\section{Competing Interests}

The authors declare that they have no competing interests.

\section{References}

1. Marshall, F. and Weissbrod, L. (2011) Domestication process and morphological change. Curr. Anthropol., 53: 397-413.

2. Soulsby, E.J.L. (1983) Helminths, Arthropods and Protozoa of Domesticated Animals. $7^{\text {th }}$ ed. The English Lingerie Book Society and Bailliere, Tindal, London.

3. Bouchery, T., Lefoulon, E., Karadjian, G., Nieguitsila, A. and Martin, C. (2013) The symbiotic role of Wolbachia in Onchocercidae and its impact on filariasis. Clin. Microbiol. Infect., 19: 131-140.

4. Hillyer, L., Coles, G. and Randle, T. (2001) Setaria equina in the UK. Vet. Rec., 149: 464.

5. Taylor, A., Latham, B. and Woolhouse, A. (2001) Risk factors for human disease emergence. Phil. Trans. R. Soc. Lond., 1411: 983-989.

6. Takaoka, H., Bain, O., Tajimi, S., Kashima, K., Nakayama, I., Korenaga, M., Aoki, C. and Otsuka, Y. (1996) Second case of zoonotic Onchocerca infection in a resident of Oita in Japan. Parasite, 3: 179-182.

7. Bahnass, M.M.A. (2005) Studies on Filariasis in Some Farm Animals. M.V. Sc. Thesis. Egypt, Faculty of Veterinary Medicine, Zagazig University.

8. El-Wab, T.M. and Raef, M. (1999) Filarid nematodes in equidae at Kafr El Sheikh province. Alex. J. Vet. Sci., 15(3): 549-565.

9. Radwan, A.M.M. (2009) An investigation on parasitic infection in equines. M.V. Sc. Thesis. Faculty of Veterinary Medicine, Benha University.

10. Al Anazi, A.D. and Alyousif, M.S. (2011) Prevalence of non-strongyle gastrointestinal parasites of horses in Riyadh region of Saudi Arabia. Saudi J. Biol. Sci., 18: 299-303.

11. Al-Azawi, K.A., Fadhl, R.A. and Fadhl, R.S. (2012) Epidemiological study of Setaria equina infection in donkeys. Iraq. Vet. J., 36(2): 93-97.

12. Arafa, M.I. (1998) Studies on ecto and endoparasites of equines in Assiut Governorate. Ph. D., Thesis. Faculty of Veterinary Medicine, Assiut University.

13. Maloufi, F. (1995) Equine parafilariosis in Iran. Vet. Parasitol., 56(1-3): 189-197.

14. Yousif, Y.A., Hayatee, Z.G., Saleem, A.N. and Joshi, H.C. (1990) Haemato-biochemical changes in microfilariae affected horses under field conditions. J. Vet. Parasitol., 4(1): 55-58.

15. Jubb, K.V.F., Kennedy, C.P. and Palmer, N. (1992) Pathology of Domestic Animals. (Book 1). $4^{\text {th }}$ ed. Academic Press, San Diego.

16. Patil, D.B., Parikh, P.V., Nisha, J., Jhala, S.K., Scholars, P., Din, U.D. and Tiwari, D.K. (2012) Equine eye worm: A review of 50 cases. Indian J. Vet. Surg., 33(1): 61-62.

17. Anderson, R.C. (2000) The superfamily Filaroidea. Nematode Parasites of Vertebrates: Their Development and Transmission. Vol. 2. CABI Publishing, New York. p467-529.

18. Enami, H.R. (2009) Epidemiological survey of equine filariasis in the Urmia area of Iran. J. Anim. Vet. Adv., 8(2): 295-296.

19. Suleiman, E.G., Aghwan, S.S. and Al-Iraqi, O.M. (2012) Detection of microfilaria infection in horses in Mosul city. Iraqi J. Vet. Sci., 26 Suppl II: 23-26.

20. Solismaa, M., Laaksonen, S., Nylund, M., Pitkänen, E., Airakorpi, R. and Oksanen, A. (2008) A filarioid nematodes in cattle, sheep and horses in Finland. Acta Vet. Scand., 50(1): 20.

21. Sellon, C.D. and Long, M. (2013) Equine Infectious Diseases. $2^{\text {nd }}$ ed. St. Louis, MI: Saunders Publishing, Co. 